\title{
Vitamin D Status and Asthma Flare-ups in Children: A Non-systematic Review
}

\author{
Samuel Nkachukwu Uwaezuoke, (1) Adaeze C Ayuk \\ Department of Paediatrics, College of Medicine, University of Nigeria, Enugu Campus, Nigeria
}

\section{ABSTRACT}

Several non-calcemic actions of vitamin D are well-documented in the literature. Its role in childhood asthma is now an area of on-going research. Studies indicate that the severity of childhood asthma is directly correlated with reduced serum vitamin $D$ levels. This non-systematic review aims to discuss the association of vitamin $D$ status with asthma flare-ups in children. We searched the PubMed database for articles that met the objective of this review. Vitamin D may play a vital role in lung health by inhibiting inflammation, partly by maintaining the regulatory $T$ cells, and by direct induction of innate antimicrobial mechanisms. Vitamin $D$ also inhibits adaptive immunity by delaying the proliferation of T-helper cells. For instance, the neutrophilic asthma phenotype is characterized by neutrophilic inflammation, whose induction is mediated by type 2 T-helper cells. Thus, vitamin $\mathrm{D}$ is related to the pathogenesis of asthma based on its ability to block the proliferation of T-helper cells. Predictably, hypovitaminosis D is associated with florid asthma symptoms, asthma flare-ups, decreased lung function, and increased drug usage, as well as severe disease. Several reports have shown a strong relationship between wheezing symptoms/asthma severity in children and low serum 25 -hydroxyvitamin D levels. These findings support the use of vitamin $D_{3}$ supplementation as a potential strategy for reducing disease flare-ups in children.

Please cite this article as: Uwaezuoke SN, Ayuk AC. Vitamin D Status and Asthma Flare-ups in Children: A Non-systematic Review. Anatol J Family Med 2019;2(3):83-90.

Address for correspondence: Dr. Samuel Nkachukwu Uwaezuoke. Department of Paediatrics, College of Medicine, University of Nigeria, Enugu Campus, Nigeria

Phone: +2348033248108

E-mail:

snuwaezuoke@yahoo.com

Received Date: 28.04.2019

Accepted Date: 12.06.2019

Published online: 11.11.2019

OCopyright 2019 by Anatolian Journal of Family Medicine -

Available online at www.anatoljfm.org

OPEN ACCESS

Keywords: Adaptive immunity, asthma, child, regulatory T-lymphocytes, helper T-cells, vitamin D deficiency

\section{INTRODUCTION}

Asthma has assumed global prominence as the most common non-communicable respiratory disease in children ${ }^{[1]}$ Asthma is now regarded as a heterogeneous disease with several phenotypes and underlying endotypes ${ }^{[2]}$ Disease heterogeneity is seen in the variable clinical presentations and the nature/extent of airway inflammation and remodeling. Asthma phenotypes and endotypes appear to represent a multitude of the host (gene)-environment reciprocal influences that occur over different periods. ${ }^{[3]}$

Epidemiologic data now indicate that dietary factors, such as hypovitaminosis $D$, are associated with florid asthma symptoms, asthma flare-ups, decreased lung function and increased drug usage, as well as severe disease. ${ }^{[4]}$ The non-calcemic actions of vitamin $\mathrm{D}$ are welldocumented in the medical literature..$^{[5-7]}$ Precisely, role of vitamin $D$ in childhood asthma is currently an area of on-going research. The research questions to be addressed should include as follows: First, whether vitamin D supplementation in infancy is protective against viral infections (which could act as triggers to asthma flare-ups). ${ }^{[8]}$ Second, whether vitamin $D$ supplementation could be administered together with inhalational steroid therapy to ameliorate disease flare-ups in school-age children. ${ }^{[8]}$ And third, whether vitamin D supplementation is more effective in populations at risk for hypovitaminosis $D{ }^{[8]}$ Several studies have highlighted 
that asthma severity in children directly correlates with low serum vitamin D levels. ${ }^{[9-12]}$ More importantly, these findings bring to the fore the potential utility of vitamin $D$ supplementation in reducing disease flare-ups in childhood, although some authors suggest that this practice cannot yet be made a general recommendation. ${ }^{[8]}$ The present non-systematic review aims to discuss the association of vitamin D status with asthma flare-ups in children.

\section{Literature Search: Strategy and Outcome}

We searched the PubMed database for articles written in the English language between January and April 2019 using the combination of two terms: 'childhood asthma and vitamin D.' The search engine yielded 198 publications, out of which we excluded 49 articles which were unrelated to the review topic. We scrutinized the remaining 149 publications for articles published within the last 25 years (19952019). We further excluded 28 papers and removed 26 duplicates, leaving 95 review articles and original articles which formed the bulk of the information used for the current narrative review (Fig. 1).

\section{The Non-calcemic Actions of Calcitriol and Asthma Pathogenesis}

Given the diverse distribution of vitamin D receptors in the human body, vitamin D has multiple non-calcemic actions. The significant non-calcemic effects of vitamin D comprise the control of hormone secretion (insulin and parathyroid hormone), immune function, as well as cellular proliferation and differentiation. ${ }^{[5]}$ The active form of vitamin $D(1$, 25-hydroxyvitamin $D$, or calcitriol) exerts different effects on innate immunity and adaptive immunity. Vitamin D stimulates the former by inducing the expression of antimicrobial peptide (cathelicidin) in myeloid and epithelial cells, ${ }^{[13,14]}$ whereas it inhibits the latter by suppressing B-cell proliferation and immunoglobulin production ${ }^{[15]}$ and retarding the proliferation of T-helper cells (Th cells) or CD4+ cells. ${ }^{[16]}$

Vitamin D may play a vital role in lung health by inhibiting inflammation, partly through maintaining the regulatory T-cells (Treg cells), and by direct induction of innate antimicrobial mechanisms. ${ }^{[4,17]}$ The primary actions of the Treg cells are immunosuppression as well as downregulation of induction and proliferation of effector T cells. ${ }^{[18]}$ As a chronic inflammatory disease, the typical clinical features of asthma occur as a result of an inappropriate stimulation of the immune system, particularly by environmental air-borne allergens. ${ }^{[19]}$ Reports show that inflammation and remodeling, especially of the respiratory epithelium and distal airways, are the distinctive features of the pathobiology of severe

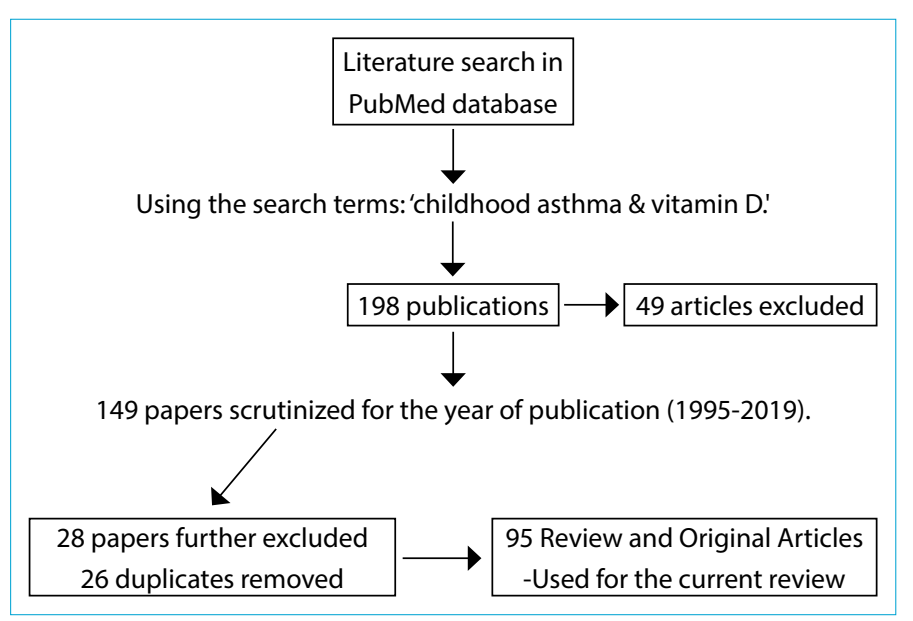

Figure 1. Literature search: strategy and outcome.

asthma in children. ${ }^{[20]}$ Severe asthma consists of multiple phenotypes, such as the inflammatory phenotypes which comprise severe allergic asthma, eosinophilic asthma, and neutrophilic asthma. ${ }^{[21]}$ Neutrophilic inflammation is the hallmark of neutrophilic asthma: a phenotype that can occur with or without eosinophilic inflammation. ${ }^{[22]}$ Induction of neutrophilic inflammation is mediated by type $2 \mathrm{~T}$-helper (Th2) cells. ${ }^{[23]}$ Furthermore, recruitment of neutrophils can be mediated by type 17 T-helper (Th17) cells, thought to be responsible for disease pathogenesis, especially in patients who do not respond to corticosteroid therapy, and show airway hyperresponsiveness and reduced improvement in airflow limitation or first second of forced expiration (FEV1) after the treatment. ${ }^{[24]}$ Vitamin $D$ influences the functions of epithelial cells, T- and Blymphocytes, and antigen-presenting cells. In addition, by inducing the Treg cells to produce interleukin-10, Vitamin D modulates inflammation in asthma and thus probably reduces disease severity. ${ }^{[25]}$ The pathogenic link between vitamin $D$ and asthma also involves the vitamin's suppressive action on the proliferation of Th cells. ${ }^{[16]}$ Given the mediatory role of Th2 and Th17 cells in neutrophilic inflammation, deficiency of vitamin D may lead to accentuation of the inflammatory processes in asthma (Fig. 2). Also, attenuation of the innate antimicrobial mechanisms following hypovitaminosis $D$ may lead to asthma flare-ups or wheezing-associated illnesses through the increased risk for respiratory tract infections. ${ }^{[26-29]}$

\section{Vitamin D Status and Asthma Flare-ups \\ Prenatal/Early-life Vitamin D Exposure and Respiratory Disorders}

Prenatal vitamin D status has been studied by several investigators to establish a link with the subsequent development of asthma. Their study methods comprised third-trimester evaluation of mothers' dietary intake of vitamin D with validated questionnaires, ${ }^{[30-33]}$ and estimation of maternal blood 


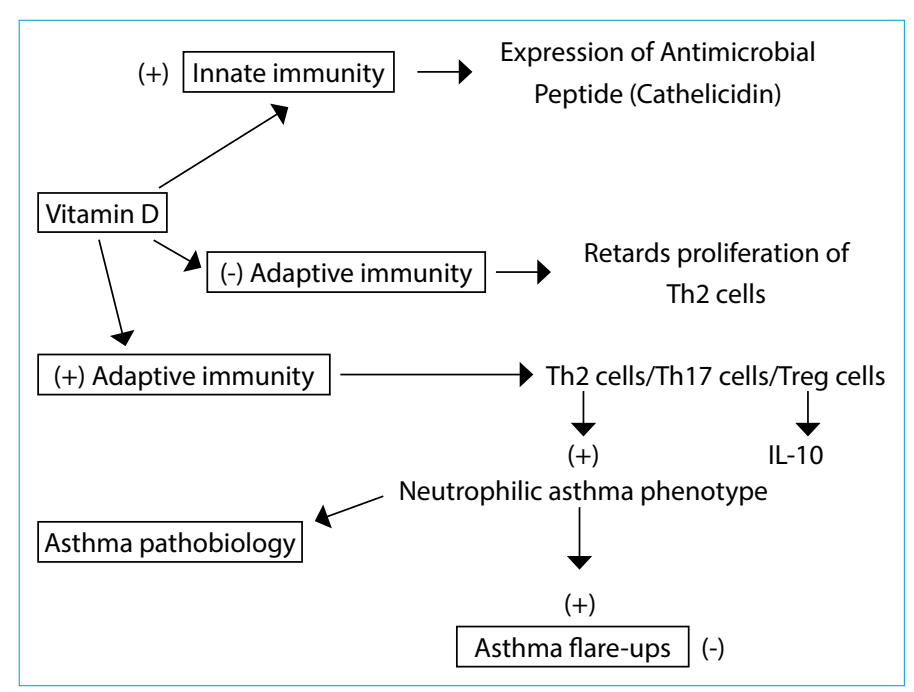

Figure 2. Schematic diagram showing the non-calcemic actions of Vitamin $\mathrm{D}$ in asthma pathobiology.

$(+)=$ stimulatory action/induction, $(-)=$ inhibitory action, Th2 cells $=$ type 2 T-helper cells, Th17 = type $17 \mathrm{~T}$-helper cells, Treg cells $=$ the regulatory T cells, IL-10 = interleukin-10.

or cord-blood vitamin D levels (Table 1).[28,29,34-37]

A prospective pre-birth cohort study of 1194 mother-child dyads by Camargo et al. in the United States aimed to investigate if higher prenatal maternal ingestion of vitamin D was associated with lower odds for repeated childhood wheezing in the third year of life. ${ }^{[30]}$ The authors evaluated mothers' prenatal ingestion of the vitamin using a validated food-frequency questionnaire (FFQ). The primary outcome of their study was a positive asthma predictive index (API), which referred to two or more wheezing episodes with a personal diagnosis of eczema or a parental history of asthma. The authors' significant finding was the association of a lower risk of recurrent wheezing (positive API) with the highest quartile of daily prenatal vitamin $D$ intake compared with the lowest quartile of daily consumption. ${ }^{[30]}$ Better still, their findings suggest that prenatal ingestion of the vitamin by mothers probably protects young children from wheezy disorders. Although the large sample size was a strong point for the study, the confounders to prenatal maternal vitamin $D$ intake (which included maternal exposure to other nutritional factors associated with asthma risk) was a study limitation. The authors adjusted for these potential confounding factors, which, however, did not alter the study results. ${ }^{[30]}$.

Elsewhere in Scotland, Devereux et al. investigated whether a similar relationship exists between prenatal maternal vitamin $D$ intake and reduced odds of wheezing in young children. ${ }^{[31]}$ They conducted a prospective birth cohort study of 2000 healthy pregnant women whose ingestion of vitamin $\mathrm{D}$ was determined in the third trimester from an FFQ. However, maternal FFQ data and respiratory parameters through the fifth year were obtained for 1212 children. The study outcomes included wheezing symptoms, spirometry, bronchodilator response, atopic sensitization and fraction of exhaled nitric oxide (FeNO) levels at five years. After adjustment for confounding variables, including the children's vitamin D consumption, the highest and lowest quartiles of total vitamin $D$ ingestion by the mothers were associated with lower odds for wheeze in the fifth year of life. Also, lower total ingestion of vitamin D by mothers during pregnancy was related to a diminished response to bronchodilators. In contrast, we should note that the researchers failed to demonstrate an associations of maternal vitamin D consumption with FeNO levels and spirometry.

In a related study of 1669 mother-child dyads by Erkkola et al. in Finland ${ }^{[32]}$ the investigators monitored the children from birth for asthma, allergic rhinitis and atopic eczema, which were assessed with a validated questionnaire at five years of age. They also evaluated maternal diet using a validated FFQ. Interestingly, the consumption of diet-derived vitamin $D$ by mothers was indirectly correlated with the risk of respiratory atopy in children after adjustment for possible confounding variables. ${ }^{[32]}$ In contrast, mothers' intake of only supplemental vitamin D was not associated with similar results. Again, the study results did not change after the authors adjusted for maternal intake of other dietary factors. ${ }^{[32]}$

The studies which ascertained maternal vitamin $D$ status through estimation of blood or cord blood levels of 25-hydroxyvitamin D were conducted in Canada, ${ }^{[34]}$ the United Kingdom, ${ }^{[35]}$ Spain $^{[36]}$ and the United States. ${ }^{[37]}$ In a crosssectional study of 344 mother-child dyads by Carroll et al., ${ }^{[34]}$ there was an observed $50 \%$ reduction in the odds of maternal asthma with every $35 \mathrm{nmol} / \mathrm{L}$ elevation in 25 -hydroxy vitamin D levels. However, the authors failed to document any association with the development of wheezing in infants of these mothers. Gale et al. noted that mothers' serum vitamin D levels of $>75 \mathrm{nmol} / \mathrm{L}$ were associated with an increased risk of atopic dermatitis and asthma in their children at the ninth month and ninth year of life respectively. ${ }^{[35]}$ The authors conducted a prospective cohort study of 466 mothers and 178 children in which they determined mothers' vitamin $D$ status by measuring their serum vitamin $D$ concentrations. The prospective cohort study by Morales et al. examined 1724 children at 12 months and 4-6 months. Maternal vitamin D status was assessed by determining the plasma 25 -hydroxy vitamin D levels. ${ }^{[36]}$

Interestingly, the investigators did not establish associations of maternal plasma vitamin $D$ levels with childhood 
Table 1. Some studies showing the effect of prenatal vitamin D status on the risk of respiratory disorders in childhood

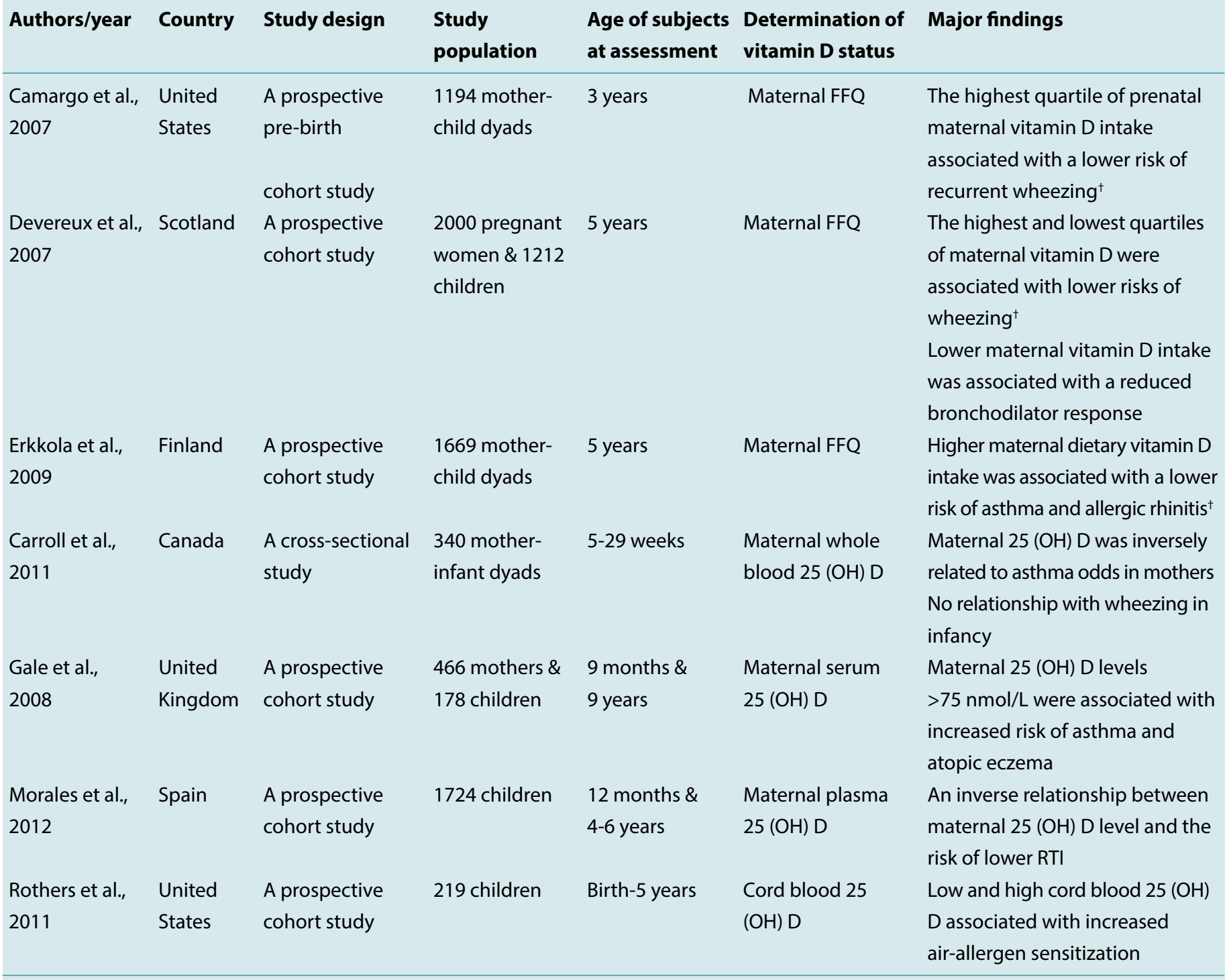

$\mathrm{FFQ}=$ food-frequency questionnaire; $\mathrm{RTI}=$ respiratory tract infections; $25(\mathrm{OH}) \mathrm{D}=25$-hydroxy vitamin $\mathrm{D} ;{ }^{\dagger}$ After an adjustment was made for potential confounders.

asthma and wheezing but observed that mothers' vitamin D status was indirectly correlated with their infants' susceptibility to lower respiratory tract infections. Finally, Rothers et al., in a prospective cohort study of 219 children, evaluated cord-blood 25-hydroxy vitamin D levels of neonates at birth. ${ }^{[37]}$ They reported that cord blood levels less than $20 \mathrm{ng} / \mathrm{ml}$ were associated with raised IgE levels and air-allergen sensitization. In contrast, there was no observed relationship between cord-blood 25-hydroxyvitamin D levels and subsequent asthma at the fifth year of life.

\section{Vitamin D Status of Children and Asthma Morbidity}

The association of childhood vitamin D status with asthma morbidity has been documented in several reports; some of these reports were observational studies, ${ }^{[38-43]}$ while other reports were clinical trials (Table 2). ${ }^{[12,44-46]}$

The cross-sectional study by Brehm et al. in Costa Rica assessed 616 pediatric asthmatic patients using biomarkers of asthma severity and allergy as outcome measures. ${ }^{[38]}$ The authors found elevated total $\operatorname{lgE}$ and eosinophilia in patients with low serum vitamin D levels. Also, elevated serum vitamin $D$ levels resulted in reduced hospitalizations, use of steroids and airway hyperresponsiveness. In a related study of 560 children with asthma $(n=287)$ and without asthma ( $n=273$ ) in Puerto Rico, Brehm et al. used outcome measures, such as severe asthma flare-ups, pul- 
Table 2. Vitamin D status in children and asthma morbidity

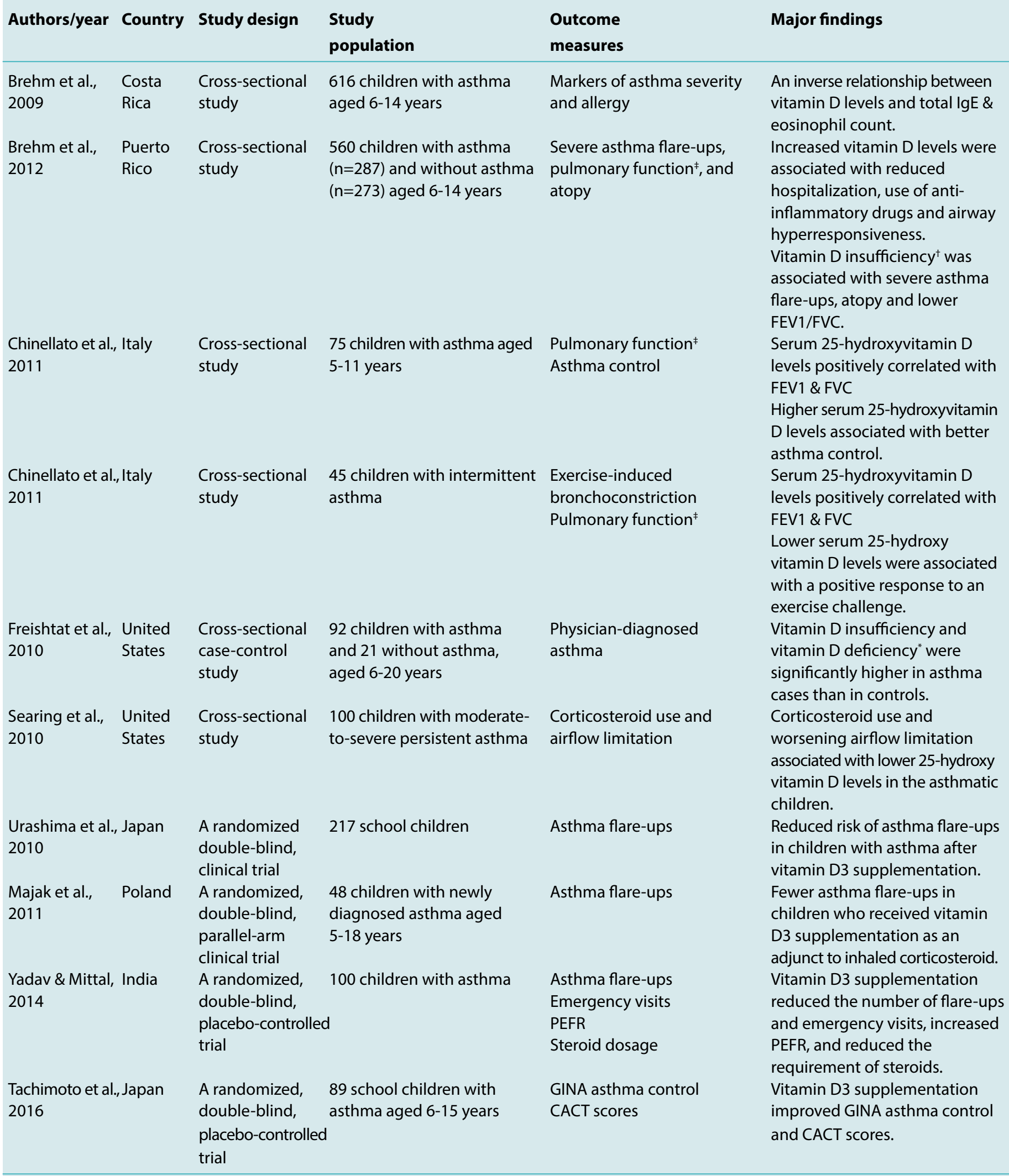

†Serum 25 -hydroxy vitamin D levels $<30 \mathrm{ng} / \mathrm{ml}$; "Serum 25 -hydroxyvitamin D levels $<20 \mathrm{ng} / \mathrm{ml}$; ${ }^{\ddagger}$ Determined by spirometry; FEV $1=$ forced expiratory volume in the first second, FVC = forced vital capacity; PEFR=peak expiratory flow rate; GINA=Global initiative for asthma, CACT=childhood asthma control test. 
monary function, and atopy, to assess the relationship between their vitamin $\mathrm{D}$ status and asthma morbidity. ${ }^{[39]}$ Vitamin D insufficiency (serum levels $<30 \mathrm{ng} / \mathrm{ml}$ ) was related to disease flare-ups, atopy and lower FEV1/FVC on spirometry. In an Italian study, Chinellato et al. investigated 75 children with asthma (using lung function and asthma control as outcome measures), ${ }^{[40]}$ and 45 children with intermittent asthma (using lung function and exercise-induced bronchoconstriction as outcome measures). ${ }^{[4]]}$ They reported a direct association of serum vitamin $D$ levels with FEV1 and FVC, as well as with better asthma control. ${ }^{[40]} \mathrm{Sim}-$ ilarly, elevated serum vitamin D levels were associated with high FEV1 and FVC values, whereas low serum vitamin D levels were associated with a positive response to an exercise challenge. ${ }^{[41]}$ Using physician-diagnosed asthma as the outcome measure, Freishtat et al. in the United States estimated the vitamin D status of 92 children with asthma and 21 children without asthma. ${ }^{[42]}$ They observed that both vitamin $D$ insufficiency and the deficiency (serum level $<20$ $\mathrm{ng} / \mathrm{ml}$ ) were significantly more elevated in asthmatic children than in their non-asthmatic counterparts. In the same country, Searing et al. evaluated the relationship between serum vitamin D levels in 100 children and asthma severity using corticosteroid use and airflow limitation as to the outcome measures. ${ }^{[43]}$ The significant findings of their cross-sectional study were the associations of steroid therapy and deteriorating airflow limitation with lower serum D levels in childhood asthma.

In clinical trials involving supplemental vitamin D3 (calcitriol) in childhood asthma, ${ }^{[12,44,45]}$ interesting results were also reported. For instance, two trials were conducted in Japan: a randomized, double-blind, clinical trial involving 217 children $^{[44]}$ and a randomized, double-blind, placebocontrolled trial on 89 school children with asthma. ${ }^{[45]}$ In the former study, asthma flare-ups were used as the outcome measures. The investigators reported a reduced risk of asthma flare-ups after vitamin D3 supplementation in their subjects. ${ }^{[44]}$ In the latter study, the outcome measures consisted of Global Initiative for Asthma asthma control and Childhood Asthma Control Test (CACT) scores. Notably, vitamin D3 supplements improved these outcome measures in the study population. ${ }^{[45]}$ Elsewhere in Poland, Majak et al. conducted a randomized, double-blind, parallel-arm clinical trial on 48 children with newly-diagnosed asthma. ${ }^{[10]}$ Using asthma flare-ups as the outcome measures for the patients who received vitamin D3 supplements as an adjunct to inhaled corticosteroid, they reported fewer flareups in these children when compared to the patients on inhaled corticosteroid alone. Finally, Yadav and Mittal in India evaluated the effects of supplemental calcitriol on 100 children with asthma in a randomized, double-blind, placebo-controlled trial. ${ }^{[12]}$ The outcome measures were asthma flare-ups, emergency visits, peak expiratory flow rate (PEFR) and steroid dosage. The major findings were the significant decrease in the frequency of flare-ups and emergency visits, PEFR elevation and decrease in steroid requirements.

\section{CONCLUSION}

There is no consensus yet on the association of maternal vitamin $D$ status with subsequent asthma/wheezing in young children. Although a preponderance of the reports suggests a positive association, a few of them suggest otherwise. Most of the observational studies have, however, shown the efficacy of vitamin D3 (calcitriol) supplementation in reducing asthma morbidity: especially disease flare-ups. Furthermore, this beneficial effect of the vitamin has been corroborated by clinical trials although their sample sizes were small. Trials with larger sample sizes should be able to provide more reliable data on this causal relationship between vitamin D status and childhood asthma. Molecular mechanisms underpinning this relationship need further exploration.

\section{Disclosures}

Peer-review: Externally peer-reviewed.

Conflict of Interest: None declared.

\section{REFERENCES}

1. Asher I, Pearce N. Global burden of asthma among children. Int J Tuberc Lung Dis 2014;18(11):1269-78. [CrossRef]

2. Bierbaum $S$, Heinzmann A. The genetics of bronchial asthma in children. Respir Med 2007;101(7):1369-75. [CrossRef]

3. Papi A, Brightling C, Pedersen SE, Reddel HK. Asthma. Lancet 2018;391(10122):783-800. [CrossRef]

4. Brown SD, Calvert HH, Fitzpatrick AM. Vitamin D and asthma. Dermatoendocrinol 2012;4(2):137-45. [CrossRef]

5. Bikle D. Nonclassic actions of vitamin D. J Clin Endocrinol Metab 2009;94(1):26-34. [CrossRef]

6. DeLuca HF. Overview of general physiologic features and functions of vitamin D. Am J Clin Nutr 2004;80:S1689S-96S.

7. Li YC. Vitamin D regulation of the renin-angiotensin system. J Cell Biochem 2003;88(2):327-31. [CrossRef]

8. Gaur SN, Singh G. Vitamin D, and asthma. Indian J Allergy Asthma Immunol 2016;30(2):55-6. [CrossRef]

9. Aldubi HM, Alissa EM, Kamfar HZ, Gaber O, Marzouki ZM. Bronchial asthma and hypovitaminosis $D$ in Saudi children. Asia Pac Allergy 2015;5(2):103-13. [CrossRef]

10. Majak P, Olszowiec-Chlebna M, Smejda K, Stelmach I. Vitamin $D$ supplementation in children may prevent asthma exacerbation triggered by acute respiratory infection. J Allergy Clin Immunol 2011;127(5):1294-6. [CrossRef] 
11. Brehm J, Schuemann B, Fuhlbrigge A, Hollis BW, Strunk RC, Zeiger RS, et al. Serum vitamin D levels and severe asthma exacerbations in the Childhood Asthma Management Program study. J Allergy Clin Immunol 2010;126(1):52-8. [CrossRef]

12. Yadav M, Mittal K. Effect of vitamin D supplementation on moderate to severe bronchial asthma. Indian J Pediatr 2014;81(7):650-4. [CrossRef]

13. Gombart AF, Borregaard N, Koeffler HP. Human cathelicidin antimicrobial peptide (CAMP) gene is a direct target of the vitamin $D$ receptor and is strongly up-regulated in myeloid cells by 1,25-dihydroxyvitamin D3. FASEB J 2005;19(9):1067-77.

14. Wang TT, Nestel FP, Bourdeau V, Nagai Y, Wang Q, Liao J, et al. Cutting edge: 1, 25-dihydroxy vitamin D3 is a direct inducer of antimicrobial peptide gene expression. J Immunol 2004;173(5):2909-12. [CrossRef]

15. Chen S, Sims GP, Chen XX, Gu YY, Chen S, Lipsky PE. Modulatory effects of 1, 25-dihydroxy vitamin D3 on human $B$ cell differentiation. J Immunol 2007;179(3):1634-47. [CrossRef]

16. Lemire JM, Archer DC, Beck L, Spiegelberg HL. Immunosuppressive actions of 1, 25-dihydroxy vitamin D3: preferential inhibition of Th1 functions. J Nutr 1995;125(6):1704S-8S.

17. Gupta A, Bush A, Hawrylowicz C, Saglani S. Vitamin D and Asthma in Children. Paediatr Respir Rev 2011;13(4):236-43.

18. Bettelli E, Carrier Y, Gao W, Korn T, Strom TB, Oukka M, et al. Reciprocal developmental pathways for the generation of pathogenic effector TH17 and regulatory T cells. Nature 2006;441 (7090): 235-8. [CrossRef]

19. Martinez FD, Vercelli D. Asthma. Lancet 2013;382(9901):136072. [CrossRef]

20. Wenzel SE, Busse WW; National Heart, Lung, and Blood Institute's Severe Asthma Research Program. Severe asthma: lessons from the Severe Asthma Research Program. J Allergy Clin Immunol 2007;119(1):14-21. [CrossRef]

21. Uwaezuoke SN, Ayuk AC, Eze JN. Severe bronchial asthma in children: a review of novel biomarkers used as predictors of the disease. J Asthma Allergy 2018;11:11-8. [CrossRef]

22. Jatakanon A, Uasuf C, Maziak W, Lim S, Chung KF, Barnes PJ. Neutrophilic inflammation in severe persistent asthma. Am J Respir Crit Care Med 1999;160(5-1):1532-9. [CrossRef]

23. Gibson PG, Simpson JL, Saltos N. Heterogeneity of airway inflammation in persistent asthma : evidence of neutrophilic inflammation and increased sputum interleukin-8. Chest 2001;119(5):1329-36. [CrossRef]

24. Barnes PJ, Adcock IM. Glucocorticoid resistance in inflammatory diseases. Lancet 2009;373(9678):1905-17. [CrossRef]

25. Maalmi H, Berraïes A, Tangour E, Ammar J, Abid H, Hamzaoui $\mathrm{K}$, et al. The impact of Vitamin $\mathrm{D}$ deficiency on immune $\mathrm{T}$ cells in asthmatic children: a case-control study. J Asthma Allergy 2012;5:11-9. [CrossRef]

26. Litonjua AA, Weiss ST. Is vitamin D deficiency to blame for the asthma epidemic? J Allergy Clin Immunol 2007;120(5):1031-
5. [CrossRef]

27. Ginde AA, Mansbach JM, Camargo CA Jr. Vitamin D, respiratory infections, and asthma. Curr Allergy Asthma Rep 2009;9(1):81-7. [CrossRef]

28. Camargo CA Jr, Ingham T, Wickens $K$, Thadhani R, Silvers KM, Epton MJ, et al. Cord-blood 25-hydroxyvitamin D levels and risk of respiratory infection, wheezing, and asthma. Pediatrics 2011;127(1):e180-7. [CrossRef]

29. Belderbos ME, Houben ML, Wilbrink B, Lentjes E, Bloemen EM, Kimpen $J \mathrm{~L}$, et al. Cord blood vitamin $\mathrm{D}$ deficiency is associated with respiratory syncytial virus bronchiolitis. Pediatrics 2011;127(6):e1513-20. [CrossRef]

30. Camargo CA Jr, Rifas-Shiman SL, Litonjua AA, Rich-Edwards JW, Weiss ST, Gold DR, et al. Maternal intake of vitamin D during pregnancy and risk of recurrent wheeze in children at 3 y of age. Am J Clin Nutr 2007;85(3):788-95. [CrossRef]

31. Devereux G, Litonjua AA, Turner SW, Craig LCA, McNeill G, Martindale $S$, et al. Maternal vitamin $D$ intake during pregnancy and early childhood wheezing. Am J Clin Nutr 2007;85(3):8539. [CrossRef]

32. Erkkola M, Kaila M, Nwaru BI, Kronberg-Kippilä C, Ahonen S, Nevalainen J, et al. Maternal vitamin D intake during pregnancy is inversely associated with asthma and allergic rhinitis in 5-year-old children. Clin Exp Allergy 2009;39(6):875-82.

33. Miyake Y, Sasaki S, Tanaka K, Hirota Y. Dairy food, calcium and vitamin $D$ intake in pregnancy, and wheeze and eczema in infants. Eur Respir J 2010;35(6):1228-34. [CrossRef]

34. Carroll KN, Gebretsadik T, Larkin EK, Dupont WD, Liu Z, Van Driest $S$, et al. Relationship of maternal vitamin $D$ level with maternal and infant respiratory disease. Am J Obstet Gynecol 2011;205(3):215.e1-7. [CrossRef]

35. Gale CR, Robinson SM, Harvey NC, Javaid MK, Jiang B, Martyn $\mathrm{CN}$, et al. Maternal vitamin $\mathrm{D}$ status during pregnancy and child outcomes. Eur J Clin Nutr 2008;62(1):68-77. [CrossRef]

36. Morales E, Romieu I, Guerra S, Ballester F, Rebagliato M, Vioque $J$, et al. Maternal vitamin D status in pregnancy and risk of lower respiratory tract infections, wheezing, and asthma in offspring. Epidemiology 2012;23(1):64-71. [CrossRef]

37. Rothers J, Wright AL, Stern DA, Halonen M, Camargo CA Jr. Cord blood 25-hydroxyvitamin $D$ levels are associated with aeroallergen sensitization in children from Tucson, Arizona. J Allergy Clin Immunol 2011;128(5):1093-9.e1-5. [CrossRef]

38. Brehm JM, Celedn JC, Soto-Quiros ME, Avila L, Hunninghake GM, Forno $E$, et al. Serum vitamin D levels and markers of severity of childhood asthma in Costa Rica. Am J Respir Crit Care Med 2009;179(9):765-71. [CrossRef]

39. Brehm JM, Acosta-Perez E, Klei L, Roeder K, Barmada MM, Boutaoui $N$, et al. Vitamin D insufficiency and severe asthma exacerbations in Puerto Rican children. Am J Respir Crit Care Med 2012;186(2):140-6. [CrossRef]

40. Chinellato I, Piazza M, Sandri M, Peroni DG, Piacentini G, Boner 
AL. Vitamin D serum levels and markers of asthma control in Italian children. J Pediatr 2011;158(3):437-41. [CrossRef]

41. Chinellato I, Piazza M, Sandri M, Peroni DG, Cardinale F, Piacentini $G L$, et al. Serum vitamin $D$ levels and exercise-induced bronchoconstriction in children with asthma. Eur Respir J 2011;37(6):1366-70. [CrossRef]

42. Freishtat RJ, Iqbal SF, Pillai DK, Klein CJ, Ryan LM, Benton AS, et al. High prevalence of vitamin $D$ deficiency among inner-city African American youth with asthma in Washington, DC. J Pediatr 2010;156(6):948-52. [CrossRef]

43. Searing DA, Zhang Y, Murphy JR, Hauk PJ, Goleva E, Leung DY.
Decreased serum vitamin D levels in children with asthma are associated with increased corticosteroid use. J Allergy Clin Immunol 2010;125(5):995-1000. [CrossRef]

44. Urashima M, Segawa T, Okazaki M, Kurihara M, Wada $Y$, Ida $H$. Randomized trial of vitamin $D$ supplementation to prevent seasonal influenza $A$ in schoolchildren. Am J Clin Nutr 2010;91(5):1255-60. [CrossRef]

45. Tachimoto $H$, Mezawa $H$, Segawa T, Akiyama N, Ida H, Urashima M. Improved control of childhood asthma with low-dose, short-term vitamin D supplementation: a randomized, double-blind, placebo-controlled trial. Allergy 2016;71(7):1001-9. 